\title{
The Democratic Control of Armed Forces in Principle and Practice
}

\author{
Simon Lunn ${ }^{1}$
}

\section{DCAF's Rise To Prominence}

The expression "democratic control" of armed forces (herein referred to as DCAF) is generally understood as the subordination of the armed forces to those democratically elected to superintend a given country's affairs. ${ }^{2}$ In its fullest sense it means that all decisions regarding the defense of the country - the organization, deployment, and use of armed forces; the setting of military priorities and requirements; and the allocation of the necessary resources - are made by democratic leadership and scrutinized by the legislative body in order to ensure popular support and legitimacy, the ultimate aim being to ensure that armed forces serve the societies they protect and that military policies and capabilities are consistent with political objectives and economic resources. While a subject in its own right, DCAF must be seen as an essential part of and, indeed, a reflection of, the broader relationship between armed forces and the societies they protect.

During the Cold War, the term DCAF evoked little discussion or debate beyond academic circles. ${ }^{3}$ In most NATO countries it was largely taken for granted, as attention focused on the potential use of armed forces in countering the threat of Soviet aggression. Since the end of the Cold War, the question of DCAF has risen to considerable prominence. A veritable cottage industry has sprung to life around it; workshops, seminars, and conferences abound; theses, studies, articles by academics and practitioners alike clutter the market. A new research center has been created in Geneva dedicated specifically to the issue. ${ }^{4}$

\footnotetext{
${ }^{1}$ Simon Lunn is the Secretary General for the NATO Parliamentary Assembly.

2 The definition of "armed forces" can be problematic. This article will refer to forces under the supervision of ministries of defense. However, in many countries, there are a variety of forces that bear arms and do not fall under the authority of the MOD - for example, police, internal security forces, or para-militaries. It goes without saying that all forces should be democratically accountable irrespective of subordination.

${ }^{3}$ The most noteworthy academic works on civil-military relations during this period were: Samuel E. Finer, The Man on Horseback: The Role of the Military in Politics (London: Pall Mall Press, 1962); Samuel P Huntington, The Soldier and the State: The Theory and Politics of Civil-Military Relations (Cambridge, MA: The Belknap Press of Harvard University Press, 1957); Morris Janowitz, The Professional Soldier: A Social and Political Portrait (New York: Free Press, 1971 [1960]); and Amos Perlmutter, The Military and Politics in Modern Times: On Professionals, Praetorians, and Revolutionary Soldiers (New Haven: Yale University Press, 1977).

${ }^{4}$ The Geneva Centre for the Democratic Control of Armed Forces (DCAF) was created through the initiative of its Director, Teddy Winkler, with the goal of providing a specific focus on an issue of widespread and growing interest and relevance. In addition to its own research program,
} 


\section{THE QUARTERLY JOURNAL}

There are a number of reasons for the sudden surge of interest in DCAF. First and foremost was the transition that took place throughout Central and Eastern Europe as former Communist countries began to develop the democratic institutions and practices that are the hallmarks of Western societies. It soon became apparent during this transitional period that the armed forces were one of the residual elements of the old regime that had to undergo fundamental change. Accustomed to civilian single party control and a privileged position in terms of resources and status, they had to be subsumed under and made responsible to the democratic processes that were being put in place. ${ }^{5}$ The issue became more pressing when NATO made clear that DCAF was one of the conditions the Alliance would be looking at in assessing the readiness of prospective members. Prominent among the objectives of NATO's Partnership for Peace initiative were the facilitation of transparency in defense planning and budgeting and assistance in ensuring democratic control of defense forces.

As a result, many would-be members and other partners have looked to the Alliance for advice and assistance as to what steps they should take. Here they encountered a central paradox. While NATO placed considerable emphasis on DCAF, no single model existed within the Alliance by way of example. For historical, cultural, and constitutional reasons, each Alliance member has adopted a different approach to the issue that defies the elaboration of a "one size fits all" formula. A series of NATO brainstorming sessions within the PfP framework shed considerable light on the various components of DCAF, but these efforts shed light equally on the many variations that exist, and therefore the difficulty of reaching a single definition was made even clearer. Agreement that "we know it when we see it, or rather we recognize when it does not exist" was about as close as these sessions came to consensus. As one Alliance participant noted at one such session "As soon as we get close to agreeing on criteria, one of us has to leave the room."

This reflected the dilemma facing the Alliance and would-be members alike, and indeed affected other NATO "criteria" - the problem of assessing when countries had reached the level judged necessary for Alliance membership. ${ }^{7}$ For the

it is hoped that the Geneva Centre will bring a degree of much-needed coordination to the many disparate activities under way in this field.

5 The national standing of the armed forces varied greatly from country to country, depending on historical experience. In Poland and Romania, the military was held in high standing, while in Hungary and the Czech Republic this was not the case. However, irrespective of their national standing as a corporate group, the several national militaries were repositories of old thinking and represented an obstacle to successful democratization.

${ }^{6}$ These formal sessions were reinforced by a plethora of workshops and seminars on the issue, many organized in aspirant countries at the initiative of Christopher Donnelly, the Special Advisor on CEE to NATO's Secretary General; another prominent player in providing assistance in the early years was the Centre for European Security Studies at Groningen, Netherlands.

${ }^{7}$ The Alliance was always careful to stress that there was no fixed or rigid list of criteria for inviting new members; readiness for membership would be a political judgment based on all relevant considerations. 
aspiring member states, the absence of a specific model had both advantages and disadvantages. On the one hand they were exposed to a variety of advice, not always consistent, as to the appropriate steps they needed to take. On the other hand, they were able to select from this advice and adapt it to their own needs and circumstances.

This focus on DCAF coincided with a period of wholesale change for the forces of Alliance members, changes which themselves have consequences for the relationships of armed forces with their societies. The armed forces of all NATO countries are in transition as they restructure, reorganize, and generally reduce away from Cold War military structures and troop levels. Many have moved, or are moving, from conscript to all-volunteer armies. The roles and missions of these forces are also changing as they are increasingly engaged in Crisis Response Operations (CRO's), missions that place new demands on the military. Furthermore, the development of new information technologies has an impact on the way armed forces operate and, by way of a seemingly omnipresent and all-pervasive media, how they are perceived to operate by the public at large.

Collectively, these factors represent a new environment and a new set of challenges to which the armed forces must respond; these adjustments in turn influence the military's in society and the relationship between the military and political institutions. The broader context of civilmilitary relations, of which DCAF is a part, is not a fixed process but is continuously evolving. All countries, NATO members and partners alike, are having to rethink the consequences of the new security environment for the way their militaries operate.

These two developments - democratization in CEE and the impact of the new security environment - have given DCAF the prominence it enjoys today. Most Alliance countries have the appropriate mechanisms in place to absorb and adjust to changes in the new environment. For countries of CEE, life has been more problematic. They have had to cope with these changes while developing the mechanisms, procedures, expertise, and attitudes of cooperation necessary to ensure effective DCAF; at the same time, and most difficult of all, they have also struggled to overcome the burden of the past. This has proved a formidable challenge.

\section{The Essential Conditions for DCAF}

While no single model was on offer, the intense discussion surrounding DCAF saw the emergence of broad guidelines concerning the basic elements that should be present in one form or another to ensure democratic control. These are:

1. Legal and constitutional mechanisms which clarify the relationships between the head of state, the government, parliament, and the armed forces in terms of the division of authority, command, and subordination in both peacetime and the transition to war; in addition, these mechanisms establish 
the roles of the relevant institutions and the status and rights of the armed forces.

2. An appropriate mix of military and civilian personnel within the MOD (including a civilian Minister of Defense) to ensure that military expertise is situated in the appropriate political and economic context.

3. Effective parliamentary oversight to ensure democratic legitimacy and popular support.

4. Maximum transparency and openness, including independent research institutes and an active and inquisitive media.

5. Armed forces at ease with their role in society.

These elements are easy to define on paper. Making them work in practice, however, is another matter. Successful implementation rests on the respective roles of the executive and the legislature, and on the relationship between them. It rests equally on the relationship of both bodies with the armed forces and on the division of responsibility and competence between the political and military sides. Developing the trust, confidence, and mutual respect on which these relationships depend lies at the heart of effective DCAF.

\section{Why Defense Is Different}

In all areas of government, a degree of tension between the executive and the legislators is inevitable in view of their respective functions. There must be a division of power and responsibility that on the one hand ensures effective action by the executive without a potentially dangerous accumulation of power, and on the other hand ensures popular support through legislative involvement but without risking paralysis of action. Establishing this balance between "efficiency" and "democracy" is crucial to ensuring effective government, and is particularly salient to the field of defense.

The need to establish such a balance is both more important and more difficult in the field of defense than in other fields of activity. Defense is not just another spending department. It brings with it certain characteristics and qualities that complicate the relationship between the executive and the legislative bodies and increase the inherent potential for friction between the two branches. There are several reasons why defense makes these relationships more difficult. The first is that defense concerns the security of the nation and involves decisions to commit lives and expenditure for the nation's defense. Decisions of this magnitude impose an additional burden of responsibility on the political leadership to get things right and to ensure that decisions and policies enjoy popular support.

The second reason is that defense involves the maintenance of armed forces. In any society, the military assume a special and distinctive position, chiefly as the 
principal possessor of weapons. Furthermore, the military also represent a highlyorganized and disciplined group, knit together by traditions, customs, and working habits, but above all by the need to work together and to depend on each other in times of crisis and conflict - a dependence that can literally mean the difference between life and death. Such dependence builds strong bonds and loyalties, and requires a degree of cohesion and group identity that few other professionals can claim. It is these qualities - discipline, dedication, and loyalty - that make the military profession different, and in some ways, distinct from society.

There are those who argue that the changing nature of war and societal trends are mitigating these differences. This is not the place to discuss this issue in detail, except to suggest that these values continue to constitute the core of "soldiering" and characterize the personal interactions that make the military function in most Alliance countries. In addition, the highly organized and structured character of military life tends to give military men a rather straightforward and uncomplicated view of the world, a view that contrasts and is often at odds with the more complex and, by comparison, apparently "murky" world of politics. Concepts of concession and compromise, essential to the balancing and reconciliation of competing interests in domestic and international politics, do not mesh easily with the clarity and directness of assessment and decision that are essential characteristics of an effectively functioning military. This can lead to widely divergent perceptions of the same problem, and can represent a source of friction between military and political actors. ${ }^{8}$ At a minimum, such friction is constrained to grumblings in the officers' mess over the doings of "our political masters." At the most extreme, it can lead to military interference with, or defiance of, the government of the day. When such episodes have occurred, it has frequently been because the military men have suggested an allegiance to a higher calling - the nation, the constitution, the people - than the transient government of the day. ${ }^{9}$ Most of our

\footnotetext{
${ }^{8}$ For a glimpse of this difference in perceptions between the man in the field (or in this case at sea) and the politicians, see the comments of Admiral Sandy Woodward, Commander of the Falklands Battle Group, as he took his force towards the Falklands: "None of our plans seems to hold up for much more than twenty-four hours, as Mr. Nott (Defense Minister) footles about, wringing his hands and worrying about his blasted career. And the Ministry men play their intricate and interminable games with an eye to the aftermath ('get in quick if there's credit, be elsewhere if there's not')." In Admiral Sandy Woodward with Patrick Robinson, One Hundred Days; The Memoirs of the Falklands Battle Group Commander (Annapolis, MD: Naval Institute Press, 1992). This text is a thoroughly readable and informative account of the problems of modern warfare, including the difficult interaction between political and military considerations. Similar frustration was expressed by General Sir Peter de la Billiere, Commander of British forces in the Gulf War, during the build-up of forces: "The level of ministerial indecision and looking backwards is appalling and desperately time wasting. There is every likelihood that we shall stay behind while the Americans go to war and our ministers dither over their decisions." In General Sir Peter de la Billiere, Storm Command, a Personal Account of the Gulf War (London: Harper Collins, 1992).

${ }^{9}$ See, for example, the well-known statement by General Douglas McCarthur: "I find in existence
} 


\section{THE QUARTERLY JOURNAL}

governments have at some time in their history experienced in differing degrees problems with a "turbulent" military. Several members of the Alliance - Turkey, Greece, Spain, and Portugal, for instance - have experienced such problems in the relatively recent past. ${ }^{10}$

Today, none of the established democracies have serious worries on this score. The respective roles of the military and civilians are well established and understood - although, as will be seen later, there are some areas where the dividing line is increasingly easily blurred. The significance of democratic control lies elsewhere, mainly in the fact that in any society the military represent a strong corporate body capable of exerting considerable influence over policy and the allocation of resources. The significance of DCAF is to ensure that the armed forces and their requirements occupy an appropriate place in the nation's priorities, that they do not absorb an undue proportion of the national resources, nor exert an undue influence on the development of policy.

For these reasons, it is important to ensure that the defense function is organized and managed in a way that maximizes military professionalism and efficiency but also guarantees political control and popular support. There is an additional dimension that makes this a difficult goal to achieve. There is a tendency for the military to believe that military things are best left to military men. This is understandable, as the business of the armed forces is to prepare for conflict and the potential loss of life. This makes the intrusions of outsiders or non-professionals a sensitive issue. This aspect will be discussed in greater detail below. It is sufficient

a new and heretofore unknown and dangerous concept that the members of our armed forces owe primary allegiance or loyalty to those who temporarily exercise the authority of the Executive branch of government rather than to the country and its constitution which they are sworn to defend." Quoted in Telford Taylor, Sword and Swastika (New York: Simon and Schuster, 1952), 354. From Russia, in a similar vein: "I have never served Tsars or Commisars or Presidents. They are mortal men and they come and go. I serve only the Russian state and the Russian people, which are eternal." General Lebed, quoted in the Financial Times, September 6, 1994. During the first of the summer schools for CEE parliamentarians organized in the mid-1990's by the NATO PA in conjunction with the George C. Marshall Center in Garmisch, there was considerable discussion of the question of whether there were ever circumstances under which the armed forces have the right to intervene internally: for example, to "save" democracy, as when the army in Algeria prevented a slate of elected Islamic fundamentalists from taking power, or when there are competing democratic institutions, as was the case when President Yeltsin used the Russian army against the Parliament. While it was agreed that there was never any justification for intervention against democratically elected authorities, it was evident that gray areas arose when the democratic legitimacy of the government itself was in question. This issue also raised questions regarding to whom armed forces pledged their oath of allegiance.

${ }^{10}$ The experiences of Spain and Portugal in making the transition to democracy and returning the armed forces to their appropriate place in society have been particularly useful examples to the new democracies. See for example, the Rose-Roth Seminar on "Defense in Democratic Societies. The Portuguese experience," Lisbon, 20-22 April 1995. The particular role of the Turkish armed forces is also frequently noted in discussions of civil-military relations and the influence of history and political culture on the place of the military in society. 
here to make three points. First, there are certainly many areas that are rightfully the preserve of the military professionals who spend their time studying and perfecting the business of war and the management of the armed forces. Second, at some stage these military activities must come under the scrutiny of the political leadership to ensure that they are consistent with, and reflect, political aims and priorities. Third, implicit in this situation in which the military accept the primacy of politics is the responsibility of the political side to ensure that it exercises informed judgment.

\section{The Role of the Executive}

The executive of any nation comprises the democratically elected or appointed leadership, whether president or prime minister, or both, plus the permanent cadre of civil servants and military officers. It is responsible for assigning defense its appropriate place in the nation's priorities, for adjudicating between competing claims, and for ensuring that defense requirements are consistent with political goals and economic resources. In other words, the executive is responsible for seeing the "big picture" and for defining the national strategy within which defense must be situated. The executive is normally responsible for the decision to go to war (with legislative approval) and for the strategic command and control of any conflict. Clarity, both of responsibility and in the line of authority, is obviously crucial.

Within the executive, the ministry (or department) of defense, together with the general staff, is responsible for the hands-on organization and management of the defense establishment and for the operation of the armed forces. This includes responsibility for the deployment and employment of armed forces, for the development of strategy and doctrine, for defense plans and budgets, for personnel policy, and for education, training, and equipping of troops. The ministry of defense has to reconcile military requirements with real-world political and economic constraints and also to arbitrate between the various services. The ministry must also establish the degree of autonomy of the armed forces and the degree of intrusiveness of political supervision.

\section{The political-military interface}

In looking at the role and responsibilities of the executive, there are three broad areas where political and military interaction is of particular interest: the question of command; the use of civilians; and the dividing line between military and political competence and responsibility.

Command: The first area of importance is the question of clarity in the arrangements for command of the armed forces in peace and in war. It goes without saying that responsibility for the decision to go to war must be clearly and unambiguously defined and that, where possible, this should be vested in a single individual, albeit subject to the agreement of the legislative body. In presidential- 
parliamentary systems, it is critical that the role of the president vis-à-vis the prime minister should be clarified. Likewise, there should be no doubt regarding to whom the chief of staff reports nor the line of authority. This again is easier said than done. No matter how tightly drafted, constitutions and legal frameworks frequently leave room for interpretation, particularly by forceful personalities.

Even the American Constitution, much admired for the simplicity of its language and the clear separation of powers, has not escaped unscathed. Under the Constitution, the President is Commander-in-Chief of the armed forces, but the Congress has the power to declare war. These definitions have left open the possibility for disputes over authority for those conflicts that fall short of a formal declaration of war yet require the deployment of American forces and sometimes the loss of American lives. U.S. forces have been deployed frequently by the President without the express authorization of Congress. ${ }^{11}$ Despite the War Powers Resolution, the debate continues today and has echoes in Congressional strictures on the deployment of U.S. forces in Bosnia and Kosovo, and now again on the potential use of military force against Iraq. This is not a comment on the merits of the arguments, but merely to indicate that even in well-established democratic systems, differences arise over who has responsibility for the use of armed forces.

Likewise, the French Constitution, which gives the president special powers for the security of the nation and the government responsibility for the management of defense, also leaves room for uncertainty, particularly in a period of socalled "cohabitation," when the president and government represent different parties. This was evident at times during the recent period of cohabitation between President Chirac and Prime Minister Jospin.

There have been several cases in Eastern and Central Europe where presidents have attempted to interpret their roles as commander-in-chief and to develop special relations with the armed forces, circumventing the government and the ministry of defense. The most notable of these was the situation in Poland when then-President Walesa attempted to assert his prerogatives over those of the government. During a meeting in 1995 with then-President of the NATO PA, Karsten Voigt, President Walesa stated that his own role as commander-in-chief of the Polish armed forces was a sufficient condition to satisfy the requirements of democratic civilian control. This proposition was diplomatically but firmly refuted. This problem was resolved by the adoption of a new Polish Defense Law and Constitution, although the president still retains considerable powers.

Role of Civilians: The second area of potential disagreement concerns the role of civilians in the ministry of defense. A standard feature of most Western democracies is that the Minister of Defense comes from a civilian background. There are a number of reasons for this, notably the fact that a civilian is considered

\footnotetext{
${ }^{11}$ See Louis Fisher, "Congressional checks on Military Initiatives," Political Science Quarterly 109:5 (1994-95); and Joseph R. Biden, Jr. and John B. Ritch, III, "The War Powers at a Constitutional Impasse: a Joint Decision Solution,” Georgetown Law Journal 77:2 (December 1988).
} 
better equipped to take account of broader policy issues and influences, and is better able to defend the MOD's turf in the competition for resources. This is not to say that military men cannot bring the same qualities to bear to the position of defense minister. However, most experience suggests that a civilian background is more appropriate to cover the full range of tasks required of the position. ${ }^{12}$

Similar questions of competence concerning the inter-changeability of civilians and military men occur regarding the role of the former in ministries of defense. Most, but not all, Western ministries of defense employ a large number of civilians to work alongside military officers in the organization and operation of the ministry. The use of civilians has clear advantages, as they bring skills in administration, management, and finance that military professionals frequently do not possess. However, many civilians also work in policy areas that take them into military territory and where, without the careful delineation of boundaries, friction can occur.

The use of civilians surfaced frequently as an issue in CEE countries during the early days of democratic transition. Most Partner CEE states, reacting to Western urgings, rather rapidly produced "civilians" in their defense ministries. However, most of these personnel were former military officers. ${ }^{13}$ This was partly due to the dearth of civilian expertise available in post-Communist countries, but also to the residual belief in the primacy of the military in defense matters. The respective roles of civilians and uniformed personnel raises the broader issue of whether service life produces an exclusively military approach that permanently influences the working methods of a military officer and therefore narrows his future employment prospects. Discussion of this issue lies beyond the scope of this paper. Clearly, much depends on the individual. Many military men make the transition to civilian policy positions (at NATO, for example) without apparent difficulty. However, the broader answer is that it is important to maximize the particular skills of both the civilian and the military, professional or retired, and ensure that they complement and reinforce each other.

The political-military dividing line: This raises the third and central issue the question of identifying the division of competence and responsibility between political and military actors. This is an issue that permeates all aspects of DCAF. Are there areas that are purely military, where the military should be allowed to get on with their business unimpeded by political interference? Common sense suggests that the answer is yes, that there are areas, such as the development of

\footnotetext{
${ }_{12}$ Again, during the first summer school for CEE parliamentarians held at Garmisch, the Western assumption that a civilian was best suited for the post of minister of defense was hotly contested by some of the CEE parliamentarians, indicating how deeply embedded were the norms of the previous Communist regimes in fencing off the field of defense for the military only.

${ }^{13}$ During an official NATO PA visit in 1994 to a Partner country, the minister of defense pointed to the civilians accompanying him as proof of civilian control. It was later pointed out that these "civilians" had been in uniform until the previous day.
} 


\section{THE QUARTERLY JOURNAL}

doctrine and tactics and the education and training of armed forces, which should be left to the military professionals. Likewise, in conflict situations, it would appear obvious that the handling of operations should be governed by professional military judgment. However, practice and experience tell a different story and suggest that few military areas are free from some form of political interference or oversight.

The final verdict has to be that all military actions are accountable at some stage to the political side. But this begs the question, At what stage should politicians exercise direct influence? Or to put it more directly, when should political judgment and authority take precedence over that of the military? This is not an easy line to define and there are a number of areas where it easily becomes blurred. The following are examples of areas where political and military interests are often in collision.

Rules of Engagement (ROE): ROEs are guidelines for the military in carrying out their mission that define their scope of action, taking full account of the political context. These cover a wide range of activities, from strategic to operational, and frequently give rise to friction between the military and political sides. At the level of grand strategy, the competing tensions between military and political requirements are best illustrated by the Cuban missile crisis. The American military sought to establish the line at which Soviet ships had to stop beyond the range of MiG fighters from Cuba, but that would have reduced the decision time for Soviet leadership. The political requirement to provide the Soviets more time - which increased the risk to U.S. forces - won the day.

Admiral Sandy Woodward, leading his Task Force towards the Falklands and uncertain about the interpretation of the ROE's he had been given, provides a graphic description of a Commander's frustration: "The picture is gloomy. The politicians are probably going to tie my hands behind my back and then be angry when I fail to pull their beastly irons out of the fire for them."14

In the same vein, the Commander of British Forces in the Gulf War, General Sir Peter De La Billiere, when facing the dilemma that his own ROE's to deal with potentially threatening Iraqi aircraft were much more restrictive than those of the American forces with whom he was deployed, responded as follows: "The politicians are ducking and weaving, and trying to avoid the real decisions they are there for. They love section-commander type decisions, like organizing uniforms or deciding on the British Forces' radio. ROE matters, where the future conduct

\footnotetext{
${ }^{14}$ Woodward, One Hundred Days. Woodward provides further comment on the question of ROE's: "I realised that considerable local amplification of the ROE was going to be central. I was sure they made excellent sense of the political interface in Whitehall, but they were sometimes less than crystal clear in the front line, where there was no time for debate as to the subtleties implied but not stated."
} 
of the war and their own and the Government's position could be in question, they avoid if at all possible." 15

The experience in Bosnia during the UNPROFOR period was replete with examples of the frustration of military commanders on the ground with the ROEs given to them by New York. NATO's own peacekeeping operations in the Balkans, while a quantum improvement on UN operations, have not been problem-free in this respect, with national ROE's frequently being more restrictive than those of the overall force, thereby hindering overall operational effectiveness.

Multi-national Operations: ROE's are part of a larger problem posed by multinational operations, whether of peace support or peace enforcement, which require a delicate balancing of military and political considerations and a imply further blurring of their respective roles. In peace support operations, such as those in Bosnia and Kosovo, many of these problems on the ground stem from the reluctance of nations to cede more than tactical control to the force commander and to retain a final veto over decisions they do not like. ${ }^{16}$ However, these operations also present entirely new challenges to armed forces, particularly in requiring the military to adopt a more political role. From the force commander to the soldier on a checkpoint, the requirement for acute political sensitivity to local conditions and the consequences of specific courses of action are overwhelming. The need for personal initiative and judgment is ever-present. ${ }^{17}$

The complications involved in multinational operations become even greater when fighting is involved. The NATO campaign against Yugoslavia provided a classic example of the interplay between political and military considerations in the conduct of such operations. Again, NATO commanders talked of fighting with their hands tied behind their backs, in particular referring to the initial targeting in the air operations and the refusal by the political leadership to countenance a ground option because of concerns over public support. ${ }^{18}$

${ }^{15}$ De la Billiere, Storm Command.

${ }^{16}$ KFOR and SFOR Commanders have frequently complained of the unwillingness of some nations to implement their decisions, particularly on the redeployment of forces.

${ }^{17}$ This new form of military involvement has led to the creation of specialist Civil Military Cooperation (CIMIC) officers in most European armed forces. The U.S. was already ahead of the game in this respect. Contrary to the thinking in some quarters, this activity and other community or nation-building activities are supported by the military. Field visits to NATO forces in Bosnia-Herzegovina and Kosovo have demonstrated the considerable pride felt by the soldiers of all nations in helping local communities recover from the trauma and damage of war. Many of the tasks undertaken by the peacekeepers require the exercise of basic military skills. Moreover, most military commanders believe that sensible rotation cycles should ensure that specialist military competences are not degraded. In other words, the roles currently being performed in the Balkans should not be disparagingly dismissed as "doing the dishes" after the real military work has been completed, but should be seen as a fundamental and indispensable part of the spectrum of military contributions to conflict management.

${ }^{18}$ For an excellent description of the operation in Kosovo and the problems of reconciling political and military requirements in such operations, see General Wesley K. Clark, Waging Modern 


\section{THE QUARTERLY JOURNAL}

As we have seen, the result of these multinational operations will be to blur even further the dividing line between military and political areas of responsibility and competence. Likewise, the trend to a more educated military encourages greater political awareness and diminishes the traditional distinction between the military and the political sides. The classical military response to questions of a political nature, heard frequently during the Cold War - "I'm just a simple soldier; that's a question for my political masters" (and it was always a misleading statement) - will be heard far less.

These new missions require the military to act in a more political sense. However, their very nature also implies greater political sensitivity to military actions, while new communications technologies mean that all military activity is within political reach. These developments will have direct consequences for DCAF and for all aspects of civil-military relations.

Procurement: The procurement of military equipment offers another example of potential friction. Frequently, military considerations on the most appropriate choice of systems are made subordinate to economic, industrial, and political considerations. Examination of the purchase of almost any major weapons system will tell the same story: the final choice is rarely decided on purely military requirements. The result is that the military frequently feel aggrieved that they have not received the optimum equipment

The military and society: Finally, there is the quite separate issue of whether military life should reflect the standards of society, for example, in the employment of women or the acceptability of homosexuals. Recent debates in the United States and the United Kingdom indicate considerable resistance on the part of the military to political pressure of this nature. This again raises the question of the distinctness of the military and the degree to which the political side should insist on policies that the military believe are inimical to their effectiveness. ${ }^{19}$

War: Bosnia, Kosovo, and the Future of Combat (New York: Public Affairs, 2001).

${ }^{19}$ For an insightful discussion of these issues, see Christopher Dandeker, "On the need to be different: Military Uniqueness and Civil-Military Relations in Modern Society," Rusi Journal (June 2001), 4. A related issue concerns the direct involvement of military personnel and civil servants in politics. In most Alliance countries, military personnel are not encouraged to be involved in politics; in the UK, they are positively discouraged. For example, "In the United Kingdom, it is regarded as a breach of professional ethics to express opinions in public about matters which are politically controversial or show preference for one political party." Presentation by A. Cragg, NATO Assistant Secretary General (on secondment from the MOD) to the seminar on "Democratic Accountability of Armed Forces," Prague, April 1995. This is not the case in all countries. The German army, with its concept of "Innere Führung" - a soldier has the same rights as a citizen - takes a very different approach, one that derives from its immediate past and the determination that never again will the German army operate at a remove from society. There is also the question of the rights of soldiers to belong to unions or associations that guarantee or protect their well-being, or whether this is incompatible with the very nature of the military profession, with its emphasis on discipline, reliability, and unquestioning obedience. Again, different countries take different positions. For an overview of these different positions, see the report on 
Each of the areas mentioned above merits detailed study; of necessity this paper has only been able to scratch the surface. The object of the discussion here has been to indicate the potential areas of friction inherent in the roles of the military and political sides in the management of defense, and also to show that the different interests and perceptions of the respective actors will continue to give rise to tensions that will require persistent adjudication and balancing.

\section{The Role of Parliament}

Before examining the role of parliaments in influencing the development and implementation of defense, two general remarks are appropriate. First, in an ideal world the role of a parliament would be not just to support the executive, but also to impose its own personality and to influence the development and the implementation of policy. ${ }^{20}$ However, in practice, many parliaments have ceded their powers of initiative to the executive. This is particularly true of security and defense policy, where there is a widespread acceptance that defense and security lie rightly within the prerogative of the executive. Frequently, parliamentary influence lies in the constraints that it is able to impose on the executive, that is, in its ability to change or reject proposals, or rather in its ability to say no. Second, many of the characteristics of defense described earlier as inhibiting or complicating the work of the executive apply equally to the work of parliaments, only more so.

The importance of parliaments for defense should be self-evident. No defense policy can endure without the support of the public it is formulated to protect. As the elected representatives of the people, parliamentarians are at the heart of the democratic system. They represent the populace from whom armed forces are drawn and whose taxes pay for their upkeep. Parliaments perform a dual function in the sense that they must both influence and reflect public opinion. It is their task to explain and justify military expenditure, in addition to explaining to their constituents why military personnel are deployed "overseas" and why such deployments may result in loss of life.

In this respect, it is worth noting that the context in which public support for the use of military force must be sustained is changing. In the absence of the direct threat present during the Cold War, armed forces are increasingly preoccupied with crises and conflicts that demand forces for power projection and rapid

the "Right to association for members of the professional staff of the armed forces," Document 9518, Committee on Legal Affairs and Human Rights, Assembly of the Council of Europe, 15 July 2002.

${ }^{20}$ The role of parliaments in defense and security cannot be divorced from the role of parliaments in general. For a discussion of the decline in parliamentary influence over the budget process, see the proceedings from "Holding the Executive Accountable: The Changing Role of Parliament in the Budget Process," Palais du Luxembourg, Paris, 24-25 January 2001. This conference was an international symposium for chairpersons of parliamentary budget committees organized by the Finance Committee of the French Senate and the Organisation for Economic Cooperation and Development. 


\section{THE QUARTERLY JOURNAL}

deployment. This has two immediate consequences. First, these missions are very demanding in terms of men and the means needed to transport and sustain them; many Alliance countries are suffering from overextension as a result of the deployments in Bosnia and Kosovo. Second, the nature of some operations makes timely consultation with parliaments extremely difficult. These trends also have implications for public support. Many of these conflicts are "remote" in the sense that they do not appear to present an immediate threat to national security, yet the media ensures that the suffering involved is brought directly into the homes of the public. This leads to the much debated "do something" factor. While for the most part the public appears to support the use of their armed forces in such situations, it is never clear to what degree this support will be sustained in the event of casualties. This is a difficult calculation for both policy makers and politicians. Hence the need to engage parliamentary support as early as possible.

If importance of parliaments to defense is indisputable, there is less agreement on what role they should play. The key issue is how much influence and control a parliament should endeavor to exert over the development of the defense budget and the organization and operation of the armed forces. With what degree of detail and intrusiveness should parliamentarians scrutinize defense?

There is, of course, no single model. Alliance parliaments exert varying degrees of influence and in different ways. ${ }^{21}$ The basic distinction to be drawn is between those who exert direct influence through formal powers of consultation and decision and those whose influence is applied indirectly through their ability to hold the executive accountable, albeit after the fact.

At one end of the spectrum there is the U.S. Congress, which, because of the U.S. Constitution and the separation of powers, plays an influential role in the development of the U.S. defense budget. Congress holds the Department of Defense firmly accountable, often in excruciating detail and in a manner described by some, particularly those on the receiving end, as excessive micro-management.

In the initial years of democratic transition, the U.S. Congress was often seen as the model for those who sought real legislative input into the defense planning process. ${ }^{22}$ However, two factors quickly became apparent: Congressional powers are not easily replicated, as they are obviously a product of, and specific to, the U.S. Constitution, which has been in place for over 200 years; and they require substantial supporting infrastructure in the way of committee staff, experts, and supporting organizations, and therefore consume substantial resources.

At the other end of the spectrum is the British Parliament, whose direct oversight consists of voting the defense budget as a global figure once a year, plus

\footnotetext{
${ }^{21}$ In a joint cooperative project, DCAF and the NATO PA are carrying out a comprehensive evaluation of the powers of parliament in defense and security in the nineteen NATO countries. Publication is expected in Autumn 2002.

${ }^{22}$ This was also because the U.S. Congress was very quick into the field in providing advice and assistance to the new parliaments, notably through the Congressional Research Service.
} 
various debates. The government does not have to obtain parliamentary approval for specific expenditure decisions. Parliament exerts little influence over the development of the British defense budget, which rests firmly in the hands of the executive. Again, this relationship is a function of British history and the development of a strong executive depending on a highly professional and relatively insular civil service.

The function of the British Parliament and its Select Committee on Defense has to be seen in a different context. It plays a major role in informing public opinion and making defense more transparent through focused hearings and reports. ${ }^{23}$ Likewise, the National Audit Office, which reports to parliament, keeps the government on its toes via in-depth assessments of various programs, looking specifically to see that expenditures have been used effectively.

Most other parliaments exert considerably more direct influence over defense than the British but fall short of the Congressional model. The German Bundestag, along with the Dutch and Danish parliaments, offer more appropriate models, as they enjoy formal consultative powers on issues such as equipment purchases and force deployments.

Within this overall distinction of direct and indirect influence, parliamentary activity can therefore be grouped into three broad areas: accountability, oversight and transparency.

Accountability: All parliaments hold their government accountable through the annual voting of necessary funds, whether this is the end of a long process of examination as in the U.S. model or the merely formal endorsement as in the British case. Whatever the model, the "power of the purse" requires every government to explain and justify its expenditure demands. Accountability is also achieved through hearings or the establishment of special committees to look into specific issues. Examples of the latter were the investigation by the Canadian Parliament into the conduct of Canadian soldiers in Somalia, and the enquiry by the Belgian Parliament into the events that led to the deaths of Belgian peacekeepers in Rwanda. ${ }^{24}$

Oversight: The crucial issue is the degree to which oversight translates into real influence over the decisions of the executive. Parliamentary authorization is an important instrument of influence. In many countries, parliamentary authorization is required for the purchase of major weapon systems, which in effect equates with participation in the decision.

\footnotetext{
${ }^{23}$ For a frank assessment of the role of the British Parliament, see the presentation of Bruce George MP (currently Chairman of the Select Committee on Defence) to the Rose-Roth Seminar on "Armed Forces in Democratic Societies", Herstmonceaux Castle, 23-26 July 1996.

${ }^{24}$ See D. J. Winslow, "The Parliamentary inquiry into the Canadian Peace Mission in Somalia," paper presented at the fourth PCAF Workshop, Brussels, July 12-14, 2002; see also the report of the Belgian Parliament on the murder of Belgian UN peacekeepers in Rwanda, "Parliamentary commission of inquiry regarding the events in Rwanda," Belgian Senate, December 6, 1997.
} 


\section{THE QUARTERLY JOURNAL}

Several Alliance parliaments have the constitutional requirement to be informed on the deployment of forces abroad, and a few have the right to participate through formal authorization. The proliferation of new missions will increase the demand for parliaments to be kept informed on a more time-sensitive basis and to be consulted on the terms of deployment. ${ }^{25}$ This will further test the balance between democracy and military efficiency, as will the use of force in conditions short of war - for example, during the air campaign against Yugoslavia, or the recent operation in Afghanistan. ${ }^{26}$ However, in all Alliance countries, regardless of the formal powers of consultation, parliamentary support is a precondition for involvement in such contingencies. Most parliaments also have the responsibility to ratify treaties, including (obviously) NATO enlargement.

The real question is how far parliaments should intrude into the making of defense policy and the operation of the armed forces. For example: should they be informed or consulted on operational matters? On development of strategy and doctrine? On procurement decisions? ${ }^{27}$ Again, the question arises regarding the dividing line between things military and political. As noted earlier, common sense suggests that there are many areas where parliament should not be directly involved in telling the military how to do their business. On the other hand, parliament should be kept fully informed through regular and timely consultation, and all areas should be open to parliamentary oversight and scrutiny. The executive should have the flexibility to exercise power responsibly but must always be mindful that parliament is watching.

Transparency: Parliamentary debates and reports help make defense more transparent and increase public awareness of defense. They play an important role in building the public consensus essential for defense. Parliamentary work on defense should form an important part of a general security environment and the creation of a defense community in which security is freely and openly discussed and ceases to be the property and prerogative of a few.

Discussion of the role of parliaments would not be complete without a mention of their role in the broader context of civil-military relations. Parliamentar-

\footnotetext{
${ }^{25}$ For a comparative review of the powers of parliaments in PSO's, see Hans Born and Marlene Ursheler, "Democratic Accountability and Parliamentary Oversight of Multinational Peace Support Operations," paper presented at he fourth PCAF Workshop on Strengthening Parliamentary Oversight, July 12-14, 2002.

${ }^{26}$ Special forces from several NATO countries including Denmark, Norway, Germany, Canada, and the UK (to name but a few) took part in the U.S.-led operation against Al Quaeda, in what were evidently sensitive operations. It would be interesting to know whether and how parliaments were consulted on the deployment of their forces. Such operations highlight the dilemma of reconciling the need for timely consultation with the need for military effectiveness of the operation.

${ }^{27}$ Some of the new parliaments initially attempted to micromanage their armed forces, even attempting, for example, to write military doctrine. Frequently this degree of intrusion was due to the suspicion with which the military was viewed rather than a realistic assessment of what was feasible and appropriate.
} 
ians form a natural link between the armed forces and the wider society. Many parliamentarians have particular connections through having military facilities or defense industries in their districts, or because they themselves have a military background. In addition, defense committees are frequently active in looking after the welfare and rights of soldiers.

What, then, are the obstacles to effective parliamentary involvement? Whatever the model and degree of involvement, parliamentary effectiveness depends on parliamentarians being well informed and knowledgeable. Once again, however, the unique characteristics of defense make the acquisition of the required competence problematic.

As a subject, defense has always lent itself to both secrecy and exclusivity - secrecy in the sense that the provision of adequate information has often been limited for reasons of national security. With the passing of the Cold War, this factor has become less inhibiting, but confidentiality still tends to limit the flow of essential information to a qualified few. Frequently, the executive is unwilling to make available desired information, on the grounds of its sensitive nature. Membership in international organizations such as NATO is often used as a reason to withhold information due to the rules of the organization, which inevitably always work at the level of the most security-conscious. Parliaments deal with the issue of confidentiality in different ways. Most work on a "need to know" basis, although it is often the executive that decides the need. Some hold closed hearings to satisfy the requirement.

Exclusivity in the sense of military sensitivity to civilian intrusion into its "territory" has already been discussed. This sensitivity is frequently more pronounced towards parliamentarians because of their perceived lack of expertise. In some instances this is understandable, because, from the military professionals' point of view, "uninformed" interference can have far-reaching consequences for the lives of service personnel. Likewise, the executive branch as a whole is frequently resistant to parliamentary involvement in defense and security. However, an unwillingness by the executive to cooperate with parliament is both wrong and ultimately counter-productive. It is wrong because it is contrary to the spirit of democracy. It is counter-productive because, no matter how irritating parliamentary scrutiny can be, parliamentary support is indispensable. Cooperation with parliaments is, as the Americans would say, a "no brainer." 28

\footnotetext{
${ }^{28}$ A revealing example of the benefits of a cooperative approach was provided during a recent NATO PA visit to Slovenia. One of the more impressive oversight roles is exercised by the Foreign Affairs Committee of the Slovene Parliament in monitoring and approving all developments in negotiations with the EU - to the extent that the Committee plans to move to Copenhagen in the latter stages of the negotiation. Asked for his reaction to this degree of involvement, the Under-Secretary admitted that at first it was a real nuisance because of the very technical nature of the issues, but that it was now seen as a real advantage because this involvement had ensured parliamentary support.
} 


\section{THE QUARTERLY JOURNAL}

A successful working relationship between the three components of DCAF - civilians, the military, and parliamentarians - depends on the various parties respecting the competence and professionalism of the others. However, developing this competence and understanding takes time and effort. Both are available for the civilian and military professional. Not so for the parliamentarian, who must first deal with a range of competing domestic pressures. Moreover, in few countries are there many election votes to be gained in being a defense or foreign policy expert. But defense is not some form of black art comprehensible only to a privileged and dedicated elite. With the appropriate supportive infrastructure, parliamentarians can develop the competence and expertise necessary to exercise responsible judgment in holding the executive accountable.

The supportive infrastructure: Effective parliamentary involvement in defense is best achieved with the help of a supportive infrastructure, which should include: qualified staff to offer reliable and informed advice on government submissions; research departments and independent research institutes to provide in-depth and objective analysis; and a critical and inquisitive media. Parliament should have access to multiple sources of information and to independent counsel so that they are not forced to rely on, or automatically accept, government submissions.

Interparliamentary organizations form an important part of this supportive infrastructure. As NATO's interparliamentary arm, the NATO Parliamentary Assembly has long been a transatlantic forum for parliamentary dialogue and a source of education, information, and experience for its members. It has played a significant role in assisting legislators to become more effective in influencing national defense policy through their national parliaments and in holding their executives to account.

The NATO PA is a policy-influencing rather than policy-making body. ${ }^{29}$ The nature of NATO's inter-governmental decision-making process based on consensus means that the contribution of its interparliamentary counterpart lies primarily in creating greater transparency of Alliance policies and contributing to the development of Alliance-wide consensus. Direct influence on NATO policies is exerted through national parliaments. ${ }^{30}$ Obviously it is to be hoped that in developing

\footnotetext{
${ }^{29}$ The NATO Parliamentary Assembly, founded in 1955 with a Brussels-based secretariat, brings together 214 national parliamentarians from the nineteen NATO countries. Associate delegations from seventeen nations, nine with the status of Parliamentary Observer, and the European Parliament also participate in a wide range of Assembly activities and meetings. The OSCE Parliamentary Assembly and the Assembly of the Western European Union also send delegations to the Assembly. For a discussion of the role of the NATO PA, see the author's paper presented to the Fourth PCAF Workshop on Strengthening Parliamentary Oversight, July 12-14, 2002: "The Role of the NATO Parliamentary Assembly."

${ }^{30}$ The emergence of the European Security and Defence Policy (ESDP) has provoked discussion on the question of democratic accountability and has led to a mini-institutional battle, with the WEU Assembly and the European Parliament as chief protagonists. Like NATO, ESDP is intergovernmental, and therefore direct accountability lies with national parliaments complemented
} 
Alliance policies, NATO's member governments take heed of the collective parliamentary voice as expressed in Assembly debates, reports and resolutions.

From 1989, the Assembly's role expanded through the integration into its work of the countries of Eastern and Central Europe. This "outreach" program now includes special seminars on issues of particular topical or regional interest: a training program for parliamentary staff, ${ }^{31}$ special cooperative arrangements with Russia and Ukraine, a Mediterranean parliamentary dialogue, and a new parliamentarians initiative. The object of this activity has been to demonstrate the Assembly's commitment to the democratic process under way in Eastern and Central Europe and to the eventual integration of partner countries into the Western community. At the practical level, they have also served to strengthen the democratic process by sharing Alliance legislative experiences, both the strengths and the weaknesses.

The parliaments of the three Baltic states were among the first to associate themselves with the NATO PA from the moment they regained their independence. The first Rose-Roth seminar was held in Vilnius in December 1991, in what were still dark and uncertain days, with Russian forces showing little inclination to return home. This was followed by similar seminars in Riga and Tallinn. Subsequently Baltic parliamentarians and staff have been enthusiastic participants in all Assembly activities. This participation allowed NATO parliamentarians to see at first hand the problems facing the new democracies; it has also allowed them to witness the impressive progress in political, military, and economic terms that has been made in all three countries.

\section{The Transition Countries}

Needless to say, most of the obstacles described earlier in establishing the norms of DCAF have already confronted the new democracies, but the transition in-

by the work of the interparliamentary assemblies. However, the overlap of ESDP with the CFSP and with Commission-funded projects in post-conflict areas such as the Balkans has given the European Parliament a toe in the water. The discussion continues. The recently created cooperative relationship between the European Parliament and the NATO PA also makes a contribution to this area and adds a much-needed degree of transparency to the status of ESDP.

${ }^{31}$ The Rose-Roth initiative was named after the two members of the U.S. Congress who initiated the program and secured the necessary funding through US AID. The Rose-Roth initiative was based on two factors: recognition of the complexity and magnitude of the problems facing new democracies in developing effective democratic institutions and a determination that the NATO PA could help. The Rose-Roth outreach program has three component parts: the integration of Eastern European parliaments into all aspects of the Assembly's work, the organization of special seminars, and staff training for parliamentary staff. The seminars (53 to date) and staff training have focused on providing advice and expertise on the development of DCAF. Overall, the program has been successful not only in providing practical experience but also in demonstrating political commitment and solidarity 


\section{THE QUARTERLY JOURNAL}

creased the magnitude of the challenges. ${ }^{32}$ In several areas the problems were worse. While all transition countries faced similar problems as a result of their Communist past, each had its own specific characteristics that made the pace of change different. The Baltic states, for example, had to start from scratch in developing their own armed forces. They did not have the enormous challenge facing others in the need to reduce and restructure bloated military establishments nor in the need to deal with a top-heavy and frequently recalcitrant officer corps. Yet no one started with a blank sheet of paper. They, like the others, had to deal with the most burdensome Communist legacy of all - mentality and attitude - and the difficulty of inculcating a sense of initiative and responsibility. This was probably the greatest problem in putting in place the necessary mechanisms and then making them work.

Most of the aspirant countries appear well on their way to overcoming these obstacles. They have developed the appropriate mechanisms, practices, and procedures for effective DCAF. Building the trust and confidence that is the basis of effective DCAF will take time, because it means changing attitudes and habits. Of course, problems and shortcomings remain. But that is also true in member countries, because the relationship between the armed forces and society is constantly evolving.

This article has emphasized the centrality of relations between the executive and the parliament, and between the military and political sides in providing effective DCAF. In Alliance countries, the tensions inherent in these relations have been absorbed through custom and practice and have become an essential element of the dynamic of democratic government. Likewise, the same process will have to work itself out in the countries that have made and are making the transition to democracy. Each country has to manage this process in its own way. The final goal is the same: finding an appropriate place for defense and the military in our respective societies. In achieving this goal, ideas and experiences can be shared and lessons learned. But the precise route chosen will be determined by forces and influences felt at home.

\footnotetext{
${ }^{32}$ For a thoughtful analysis of the experiences, problems, and progress made by four parliaments, see David Betz, "Comparing Frameworks of Parliamentary Oversight: Poland, Hungary, Russia, Ukraine," paper presented to a seminar on "Democratic Control of Armed Forces in Croatia," Zagreb, 26 October 2001.
} 


\section{Bibliography}

Biden, Joseph R., and John B. Ritch. "The War Powers at a Constitutional Impasse: a Joint Decision Solution." Georgetown Law Journal 77, no. 2 (1995).

Finer, Samuel E.. The Man on Horseback: The Role of the Military in Politics . London: Pall Mall Press, 1962.

Fisher, Louis. "Congressional checks on Military Initiatives." Political Science Quarterly 109, no. 5 (1995).

Huntington, Samuel P.. The Soldier and the State: The Theory and Politics of CivilMilitary Relations. Cambridge, MA: Harvard University Press, 1985.

Janowitz, Morris. The Professional Soldier: A Social and Political Portrait. New York, Free Press, 1960.

Perlmutter, Amos. The Military and Politics in Modern Times: On Professionals, Praetorians, and Revolutionary Soldiers . New Haven: Yale University Press, 1977.

Robinson, Patrick. One Hundred Days; The Memoirs of the Falklands Battle Group Commander . Annapolis, MD: Naval Institute Press, 1992. 